\title{
KEGIATAN PENGEMBANGAN KOMPETENSI PEMANDUAN WISATA STP BANDUNG DI DESA WISATA SUNTENJAYA KABUPATEN BANDUNG BARAT
}

\author{
Faisal Fahdian Puksi ${ }^{1}$, Endang Komesty Sinaga ${ }^{2}$, Cucu Kurniati ${ }^{3}$, Nuraeni Handayaningrum ${ }^{4}$ \\ ${ }^{1}$ Sekolah Tinggi Pariwisata Bandung \\ ${ }^{2}$ Sekolah Tinggi Pariwisata Bandung \\ ${ }^{3}$ Sekolah Tinggi Pariwisata Bandung \\ ${ }^{4}$ Sekolah Tinggi Pariwisata Bandung
}

faisalpuksi@gmail.com, enk@stp-bandung.ac.id,cuk.stpb@yahoo.com,ningrum0312@gmail.com

\begin{abstract}
Abstrak
Potensi besar yang dimiliki Desa Wisata Suntenjaya di Kabupaten Bandung Barat tidak diimbangi dengan tersedianya sumber daya manusia pariwisata yang terlatih dan profesional. Oleh karena itu, dibutuhkan dukungan dalam pengembangan kompetensi pemanduan wisata melalui suatu program pengabdian masyarakat. Untuk mendukung hal tersebut, pada November 2019, dilaksanakan kegiatan pengabdian masyarakat terkait pemanduan wisata. Tujuan kegiatan ini adalah memberdayakan potensi masyarakat Desa Wisata Suntenjaya dalam meningkatkan kemampuan pemanduan wisata. Kegiatan dikemas dalam bentuk workshop yang dilaksanakan tiga hari sehingga pada setiap akhir sesi, peserta memiliki hasil yang dapat langsung digunakan nanti saat menerima wisatawan. Materi workshop yang dibahas adalah pelayanan prima, bahasa Inggris dasar, pengetahuan daya tarik wisata, serta teknik interpretasi dan teknik memandu wisatawan. Peserta kegiatan ini adalah 20 orang masyarakat desa wisata Suntenjaya yang memiliki pekerjaan utama sebagai petani, peternak, dan anggota Karang Taruna. Tim pengabdian kepada masyarakat terdiri dari empat orang dosen Sekolah Tinggi Pariwisata Bandung yang didukung oleh lima orang mahasiswa. Hasil dari kegiatan ini adalah SOP pemanduan wisata, daftar daya tarik potensial, pola aktivitas wisata, dan skrip pemanduan wisata. Selain itu, kemampuan pemanduan wisata masyarakat desa juga diharapkan meningkat dengan dilaksanakannya praktek pemanduan wisata. Saran agar kegiatan ini berlanjut adalah perlu pendampingan dari berbagai bidang agar masyarakat desa wisata Suntenjaya memiliki kompetensi pariwisata yang lengkap dan menyeluruh.
\end{abstract}

Kata Kunci: Kompetensi, Pemanduan Wisata, Wisata Agro, Desa Wisata Suntenjaya

\section{PENDAHULUAN}

Kabupaten Bandung Barat dikenal memiliki berbagai potensi pariwisata yang sangat besar, terutama wisata alam. Selain potensi daerah di sektor agro baik pertanian, perkebunan, kehutanan, peternakan dan perikanan, Kabupaten Bandung
Barat juga memiliki beberapa potensi di bidang pariwisata baik wisata alam, wisata minat khusus maupun jenis wisata lainnya. Berbagai upaya dilakukan pemerintah daerah Kabupaten Bandung Barat untuk memajukan pariwisata di daerah tersebut. Salah satu upaya yang dilakukan oleh Pemda Kabupaten Bandung Barat adalah 
pengembangan kawasan wisata Kabupaten Bandung Barat dalam 3 zona wisata utama, yaitu Zona Bandung Utara, Bandung Selatan, dan Bandung Barat. Selain itu, pemerintah daerah juga menetapkan beberapa desa menjadi desa wisata. Pada tahun 2014 Pemerintah Kabupaten Bandung Barat menetapkan lima desa menjadi desa wisata. Kelima desa wisata tersebut adalah Suntenjaya di Kecamatan Lembang, Rende (Cikalongwetan), Sirnajaya (Gununghalu), Mukapayung (Cililin), dan Cihanjuang Rahayu (Parongpong). Desa Suntenjaya memiliki potensi pariwisata yang sangat besar, namun membutuhkan dukungan dari berbagai pihak dalam pengembangan kapasitas sumber daya manusia.

Desa Suntenjaya yang berada pada ketinggian $1260 \mathrm{Dpl}$ memiliki potensi alam yang dapat meningkatkan kesejahteraan masyarakat. Selain pertanian dan peternakan, Desa Suntenjaya menjadi daerah tujuan wisatawan, baik lokal maupun asing. Sehingga pemerintah menobatkan desa ini sebagai desa wisata. Dengan kondisi geografis yang dimiliki, Desa Suntenjaya telah banyak memberikan manfaat bagi warganya. Mulai dari pertanian, peternakan, perkebunan hingga pariwisata, menjadi sektor utama yang memberikan peningkatan ekonomi masyarakat Desa Suntenjaya. Hingga saat ini sektor pariwisata terus dikembangkan (Nuryati, 2017).

Berdasarkan hasil pembicaraan awal dengan pengurus desa wisata (Bapak Nandang) dan studi kepustakaan (Saepudin dkk, 2017; Nuryati, 2017) diketahui bahwa terdapat beberapa poin pengembangan yang perlu dilakukan diantaranya: 1) Penyusunan potensi alam dan budaya menjadi paket wisata, 2) Peningkatan kemampuan pengelola dalam hal pemanduan wisata, 3) Peningkatkan kualitas pelayanan wisata, 4) Peningkatan kemampuan berbahasa Inggris.

Untuk mengembangkan desa wisata ini diperlukan sumber daya manusia yang handal dan berkarakter. Oleh karena itu pelatihan dalam bentuk workshop kepada pengelola desa wisata dan masyarakat desa yang terlibat dalam kegiatan pariwisata di Desa Wisata Suntenjaya sangat diperlukan. Sekolah Tinggi Pariwisata Bandung membentuk tim pengabdian masyarakat dengan lokus desa wisata Suntenjaya untuk mengembangkan kompetensi pariwisata masyarakat, terutam terkait pemanduan wisata.

Kegiatan pengabdian kepada masyarakat yang dilakukan kelompok ini dilakukan terkait dengan bagaimana masyarakat di Desa Desa Wisata Suntenjaya Kabupaten Bandung Barat merancang suatu bisnis atau usaha dengan kearifan lokal, dalam hal pengemasan dan membuat harga jual produk yang lebih kompetitif.

Oleh karena itu perlu dilakukan penyuluhan dan pendampingan kepada para pelaku Usaha Kecil Menengah (UKM) termasuk di dalamnya pembenahan sumber daya manusia agar mereka memiliki jiwa ekonomi kreatif dalam meningkatkan pertumbuhan ekonomi masyarakat Desa Desa Wisata Suntenjaya Kabupaten Bandung Barat. Kegiatan Pengabdian masyarakat ini sekaligus secara teratur menumbuh kembangkan kebiasaan intelektual dalam kegiatan pendidikan, sehingga memiliki relevansi dalam agenda Tri Dharma Perguruan Tinggi di bidang pendidikan, penelitian, dan pengabdian masyarakat.

Tujuan pengabdian masyarakat di Desa Wisata Suntenjaya adalah 1) memberdayakan potensi masyarakat Desa Wisata Suntenjaya dalam meningkatkan pendapatan keluarga melalui peningkatan usaha ekonomi produktif. 2) Terciptanya paket wisata yang baru yang dapat dijual kepada wisatawan. 3) Terjadi peningkatan jumlah wisatawan yang berkunjung ke Desa Wisata Suntenjaya.

Sasaran pengabdian masyarakat di Desa Wisata Suntenjaya adalah masyarakat mampu menyusun paket wisata, mampu mengemas paket wisata, dan mampu menangani operasional tour. Keluaran dari program ini adalah tersedianya panduan teknik pemanduan wisata dan desain produk paket wisata yang disiapkan yang disiapkan oleh peserta pengabdian masyarakat.

\section{METODE}

Dalam kegiatan pengabdian kepada masyarakat ini metode pelaksanaan kegiatan dilaksanakan dalam bentuk workshop dengan dua metode yaitu paparan presentasi dan simulasi 
praktek. Metode paparan presentasi dan simulasi praktek sangat penting untuk mendukung kegiatan workshop (Sukanadi dan Wardana, 2017)

Paparan presentasi (30\%): dalam metode ini tim PKM melakukan pemaparan mengenai pemahaman dasar pemanduan wisata, teknik pemanduan wisata, cara penyusunan pemanduan wisata, dan cara berkomunikasi dalam bahasa Inggris secara efektif. Kegiatan ini dilaksanakan di kantor Pokdarwis Desa Suntenjaya.

Simulasi praktek (70\%): setelah dilakukan paparan presentasi, setiap peserta kemudian diminta untuk mengerjakan sendiri penyusunan paket wisata lalu praktek simulasi pemanduan wisata, serta berinteraksi dengan menggunakan bahasa Inggris.

\section{HASIL DAN PEMBAHASAN}

\section{Hasil dan Pembahasan}

Dengan kondisi geografis yang dimiliki, Desa Suntenjaya telah banyak memberikan manfaat bagi warganya. Mulai dari pertanian, peternakan, perkebunan hingga pariwisata, menjadi sektor utama yang memberikan peningkatan ekonomi masyarakat Desa Suntenjaya. Hingga saat ini sektor pariwisata terus dikembangkan di Desa Wisata Suntenjaya. Wisata utama yang berkembang di Suntenjaya saat ini adalah wisata agro yang terdiri dari peternakan sapi, pertanian sayu-sayuran, perkebunan kopi, budidaya ikan dan cacing, serta berbagai kegiatan wisata agro lainnya. Di kiri dan kanan desa, terdapat perbukitan dan gunung, yaitu Gunung Palasari, Gunung Manglayang, Bukit Tunggul, dan air terjun. Selain wisata agro dan wisata air terjun, saat ini juga tengah dikembangkan wisata budaya. Di salah satu kampung, yaitu Kampung Batu Loceng terdapat situs batu loceng. Banyak masyarakat berbagai daerah berziarah ke situs tersebut. Selain itu, desa tersebut menjadi salah satu lokasi pertukaran pelajar dari mancanegara melakukan kegiatan sosial.

Desa Wisata Suntenjaya memiliki potensi alam dan budaya yang diakui oleh pemerintah daerah maupun wisatawan. Namun demikian, dalam beberapa tahun belakangan ini tidak terjadi peningkatan jumlah kunjungan wisatawan, bahkan cenderung menurun. Hal ini terjadi karena kurangnya keahlian menyusun paket wisata sehingga paket wisata yang ada tidak up-to-date, perlunya peningkatan kemampuan pemanduan wisata, dan peningkatan kemampuan berbahasa Inggris. Sehingga untuk mengatasi permasalahan tersebut, diperlukan dukungan peningkatan sumber daya manusia di Desa Wisata Suntenjaya melalui pelatihan peningkatan kompetensi kepemanduan wisata, yang di dalamnya mencakup teknik pemanduan wisata, penyusunan paket wisata, dan komunikasi berbahasa Inggris.

Mitra dalam Program Kemitraan Masyarakat ini adalah petani dengan latar belakang pendidikan yang bervariasi, namun sebagian besar memiliki latar belakang pendidikan minimal SMP dan SMA. Status sosial masyarakat Desa Wisata Suntenjaya pada umumnya adalah petani. Profesi peserta kegiatan pengabdian kepada masyarakat adalah petani kopi, petani sayur-sayuran, peternak sapi, dan perangkat desa Suntenjaya.

Kegiatan workshop dilaksanakan selama 3 hari dengan jadwal sebagai berikut:

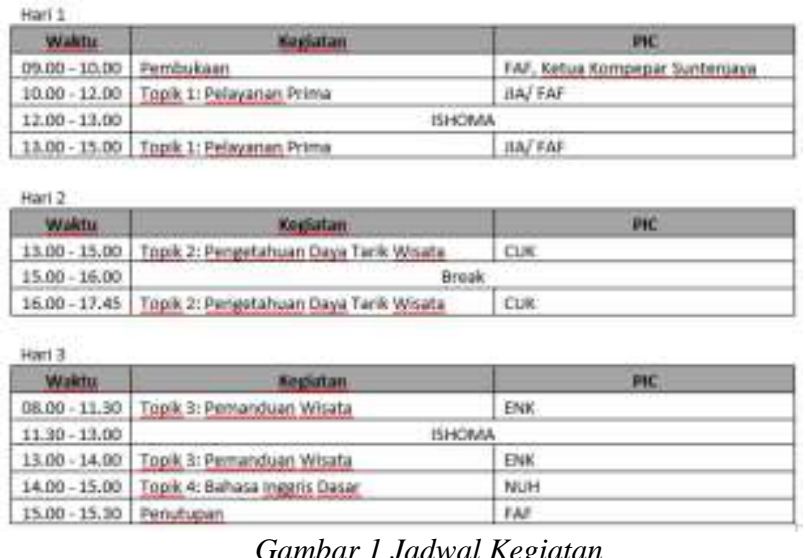

Gambar 1 Jadwal Kegiatan

Selama pelaksanaan kegiatan pengabdian kepada masyarakat ini, peserta kegiatan antusias untuk mengikuti kegiatan sepanjang hari. Peserta kegiatan yang sebagian besar adalah petani bersedia untuk mengikuti workshop dan menitipkan pekerjaan pertanian kepada kerabatnya. Workshop dibagi menjadi 4 bagian yang terdiri dari pelayanan prima, bahasa Inggris dasar, pengetahuan daya tarik wisata, serta teknik interpretasi dan teknik memandu wisatawan.

Pelayanan merupakan proses interaksi antara seseorang yang berupaya memenuhi kebutuhan dengan seseorang yang ingin terpenuhi kebutuhannya. yaitu antara pelanggan/ tamu/ klien/ nasabah/ pasien dan para petugas/ karyawan/ pegawai. Pelayanan adalah suatu tindakan yang

Pendidikan 669 
dilakukan guna memenuhi keinginan customer (pelanggan) akan suatu produk/ jasa yang mereka butuhkan, tindakan ini dilakukan untuk memberikan kepuasan kepada pelanggan/ customer untuk memenuhi apa yang mereka butuhkan tersebut (Barata, 2003).

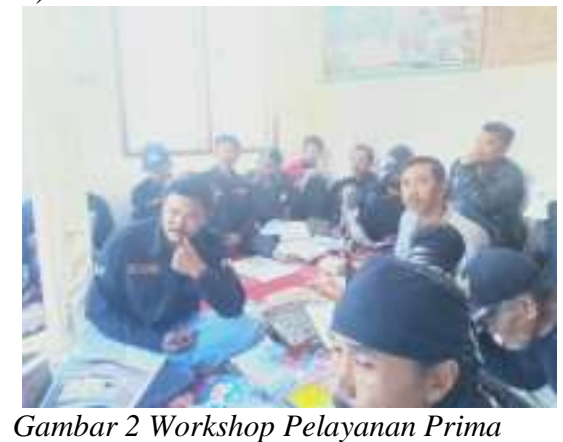

Pelayanan prima dalam workshop ini dilaksanakan agar masyarakat desa wisata Suntenjaya dapat memberikan pelayanan secara maksimal kepada wisatawan. Wisatawan yang mendapatkan pelayanan dengan baik dari masyarakat desa wisata dapat memiliki kesan dan pengalaman yang baik sehingga dapat meningkatkan potensi kunjungan berulang dan promosi word of mouth (Hanif dkk, 2016).

Pengetahuan daya tarik wisata dikembangkan dalam workshop ini agar masyarakat desa wisata Suntenjaya dapat lebih mengenal berbagai daya tarik wisata yang tersedia di desa Suntenjaya, baik yang sudah maju maupun berpotensi untuk berkembang. Pengetahuan geografi menjadi basis dalam pengetahuan daya tarik wisata.

Geografi digunakan sebagai alat dalam merencanakan kegiatan dan program pariwisata di suatu daya tarik wisata. Ilmu geografi, khususnya geografi sosial dapat dijadikan sumber informasi dasar pasar wisata untuk desa wisata Suntenjaya. Komponen geografi pariwisata yang harus dipahami peserta adalah daerah asal wisatawan, daerah tujuan wisata, dan rute antara (Kurniawan dan Tanjung, 2017).

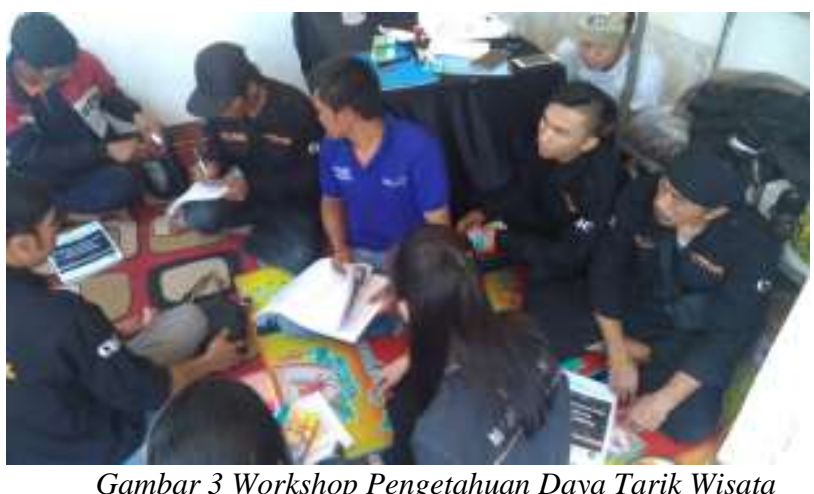

Gambar 3 Workshop Pengetahuan Daya Tarik Wisata

Peserta kegiatan kemudian didampingin untuk mengidentifikasi berbagai daya tarik wisata yang tersedia di desa wisata Suntenjaya. Peserta kegiatan diminta untuk mengisi formulir sebagai berikut:

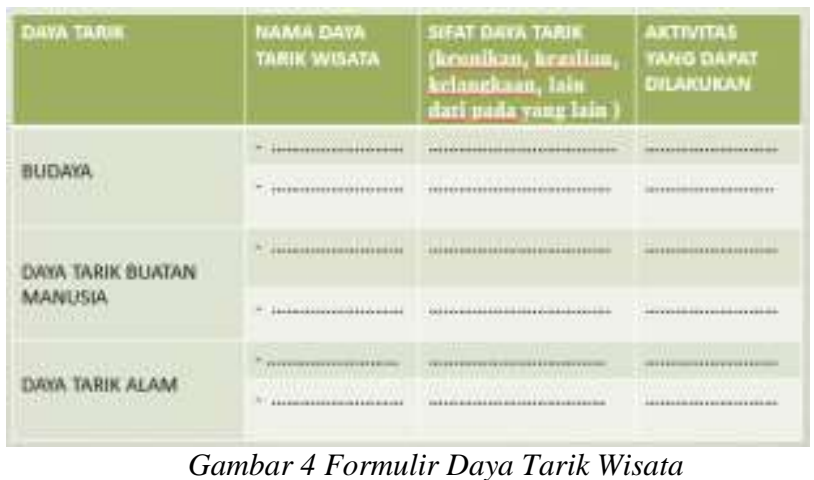

Dalam pemanduan wisata, teknik interpretasi dan teknik memandu wisatawan merupakan komponen yang sangat penting untuk dikuasai. Peserta kegiatan workshop ini diajarkan dan didampingi untuk menguasi dua teknik kepemanduan wisata ini. Peserta kegiatan didorong untuk menguasai kepemanduan wisata dasar dan mampu menguasai kompetensi dasar pramuwisata. Topik yang dibahas disesuaikan dengan kompetensi pemandu wisata menurut Jumail (2014), yaitu pemandu harus bisa menyiapkan mulai dari menyiapkan, melaksanakan, hingga mengevaluasi kegiatan pemanduan wisata.

Pemandu wisata atau pramuwisata memiliki beberapa pengertian. Pemandu wisata adalah seseorang yang memandu wisatawan dan menginterpretasikan warisan budaya serta alam dari Nama Sub tema Penelitian 670 
suatu daerah (Kristiana, dkk, 2017). Pramuwisata adalah seseorang yang memimpin dan bertugas memberi bimbingan, penjelasan, dan petunjuk tentang objek wisata serta membantu segala sesuatu yang dilakukan wisatawan dari persiapan sampai pada akhir suatu kegiatan wisata (Kesrul, 2004).

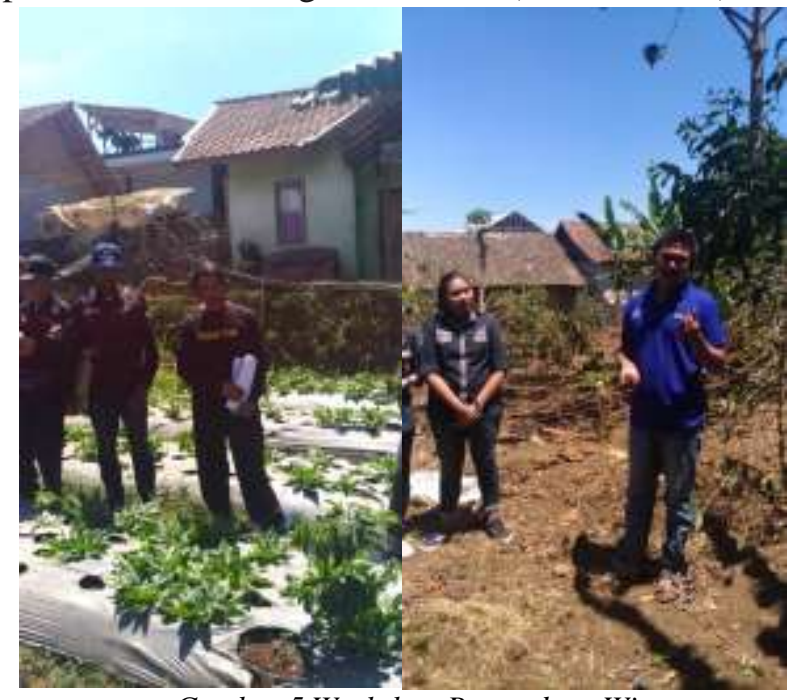

Gambar 5 Workshop Pemanduan Wisata

Teknik pemanduan wisata yang diajarkan kepada peserta adalah pemanduan awal, proses pemanduan utama, dan akhir pemanduan. Peserta juga didampingi dalam membuat komentar pemanduan (guiding commentary) dalam menginterpretasikan produk pariwisata yang dimiliki. Dalam kegiatan ini seluruh peserta diminta untuk memahami tugas-tugas pramuwisata (Mukti, 2005), yaitu 1) mengantar wisatawan, 2) memberikan penjelasan tentang rencana perjalanan, 3) memberikan petunjuk tentang obyek wisata, 4) membantu pengurusan barang bawaan wisatawan, 5) menolong wisatawan yang membutuhkan pertolongan.

Materi terakhir dalam workshop ini adalah Bahasa Inggris dasar. Bahasa Inggris yang diajarkan sangat dasar dengan topik memperkenalkan diri dan petunjuk arah. Bahasa Inggris dasar menjadi sangat penting untuk pengelola desa wisata agar dapat menerima wisatawan mancanegara. Meskipun peserta tidak dapat menguasai Bahasa Inggris dengan sangat fasih, setidaknya peserta kegiatan dapat memahami dan mengetahui istilah dasar Bahasa Inggris.

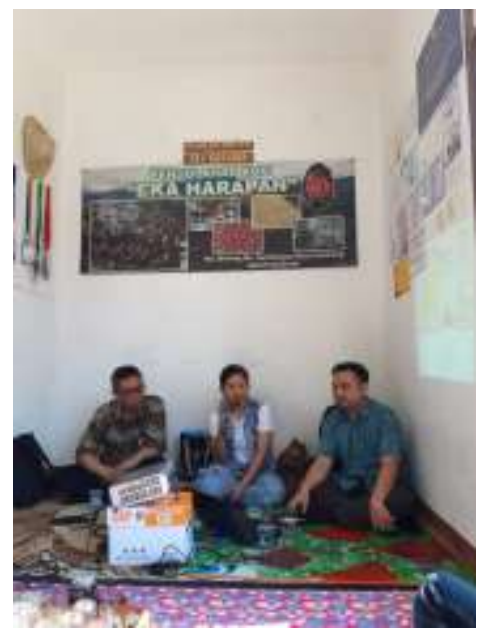

Gambar 6 Workshop Teknik Pemanduan Wisata

Pada akhir sesi, setiap peserta diminta untuk mempraktekkan seluruh materi yang sudah dipelajari. Peserta diminta untuk menjadi pemandu wisata pada dua tempat, yaitu kebun kopi dan kebun sayur.

Masyarakat sangat mendukung pelaksanaan pengabdian kepada masyarakat di desa wisata Suntenjaya. Peserta yang berminat untuk mengikuti kegiatan ini mencapai 35 orang, namun karena keterbatasan anggaran dan ruangan kegiatan maka peserta yang dapat diakomodir hanya 20 orang. Kepala Desa Suntenjaya pun sangat mendukung kegiatan ini, dan mengarahkan kegiatan pengabdian kepada masyarakat ke Kelompok Sadar Wisata Desa Suntenjaya agar pelatihan yang diberikan tepat sasaran.

Pengabdian kepada masyarakat yang dilakukan oleh tim memiliki dampak yang sangat baik dalam pengelolaan desa wisata Suntenjaya. Metode yang digunakan lebih menitikberatkan pada simulasi praktek di lapangan langsung sehingga peserta dapat memahami mengenai konten pelatihan yang diberikan dan memiliki pengalaman langsung dalam membawa wisatawan. Hasil kegiatan yang diperoleh adalah pemahaman mengenai pelayanan prima, identifikasi daya tarik wisata, kemampuan bahasa Inggris dasar, dan pemanduan wisata. Kegiatan ini dilaksanakan selama tiga hari sehingga pada setiap akhir sesi masyarakat Desa Wisata Suntenjaya memiliki hasil yang dapat langsung digunakan nanti saat menerima wisatawan.

Untuk mendukung keberlanjutan kegiatan ini, dilakukan monitoring dan evaluasi secara Pendidikan 671 
berkala yang dilakukan oleh tim setiap tahun terhadap peserta kegiatan di Desa Wisata Suntenjaya. Hasil yang dapat diketahui dari monitoring dan evaluasi yang dilakukan adalah semakin tingginya minat masyarakat untuk terlibat dalam kegiatan pariwisata di desanya. Selain itu, dapat diketahui bahwa perlu dilaksanakan kegiatan pengabdian kepada masyarakat lanjutan dengan topik yang berbeda. Pendampingan dan pelatihan di Desa Wisata Suntenjaya dari bidang lain seperti standarisasi homestay, higienitas makanan, dan penguatan paket wisata dapat memperkuat kompetensi masyarakat terkait pariwisata secara lebih menyeluruh.

\section{KESIMPULAN DAN SARAN}

Model kegiatan dalam PKM ini adalah pelatihan sebagai bentuk peningkatan kapasitas masyarakat desa sehingga dapat memberikan manfaat untuk masyarakat Desa Wisata Suntenjaya. Model pelatihan yang diberikan lebih bersifat pendampingan yang disesuikan dengan kebutuhan desa wisata sehingga masyarakat desa memperoleh kemampuan yang diharapkan untuk meningkatkan kualitas dan kuantitas wisatawan.

Untuk mendukung keberlanjutan pengembangan kompetensi masyarakat desa wisata Suntenjaya, diperlukan pendampingan dan pelatihan dari bidang lain seperti standarisasi homestay, higienitas makanan, paket wisata, dan lain sebagainya. Pendampingan dan pelatihan dari berbagai bidang diperlukan agar masyarakat desa wisata Suntenjaya memiliki kompetensi pariwisata yang lengkap dan menyeluruh.

\section{UCAPAN TERIMAKASIH}

Tim Pengabdian Kepada Masyarakat STP Bandung mengucapkan terima kasih yang sebesarnya-besarnya kepada seluruh pihak yang terlibat dalam kegiatan tersebut.

\section{REFERENSI}

Barata, A. A. (2003). Dasar-dasar pelayanan prima. Elex Media Komputindo.

Hanif, A., Kusumawati, A., Mawardi, M. K. (2016). Pengaruh Citra Destinasi Terhadap Kepuasan Wisatawan Serta Dampaknya Terhadap Loyalitas Wisatawan (Studi pada Wisatawan Nusantara yang Berkunjung ke Kota Batu). Jurnal Administrasi Bisnis, 38(1), 44-52.

Jumail. (2014). Teknik pemanduan wisata. Penerbit Andi.

Kesrul, M. (2004). Panduan Praktis Pramuwisata Profesional. Yogyakarta: Graha Ilmu.

Kristiana, Y., Sinulingga, P., dan Lestari, R. (2018). Kunci Sukses Pemandu Wisata. Deepublish.

Kurniawan, H., dan Tanjung, M. R. (2017). Sistem informasi geografis objek Wisata Alam di Provinsi Sumatera Utara berbasis mobile android. Sisfotenika, 7(1), 13-24.

Mukti, A. B. (2005). Peranan Pramuwisata Dalam Perjalanan Wisata. Jurnal Ilmiah Dinamika Kepariwisataan, 3(1).

Nuryati, Nunung. (2017). Pengembangan Desa Suntenjaya menjadi desa wisata di Kecamatan Lembang Kabupaten Bandung Barat. Universitas Pendidikan Indonesia.

Saepudin, E., Budiono, A., Rusmana, A. (2017). Karakteristik pramuwisata dalam pengembangan desa wisata agro di Kabupaten Bandung Barat. Jurnal Ilmu Sosial dan Humaniora. 6. 51. 10.23887/jish-undiksha.v6i1.9689.

Sukanadi, N. L., dan Wardana, I. K. (2017). Pengaruh Metode Pelatihan dan Simulasi Terhadap Pengajaran Guru-Guru Bahasa Asing SMK Pariwisata. Jurnal Bakti Saraswati (JBS): Media Publikasi Penelitian dan Penerapan Ipteks, 6(2), 83-91. 